\title{
INTRODUCTION TO THE SPECIAL ISSUE ON THE RIGHT TO EDUCATION
}

On December 10, 1948 the General Assembly of the United Nations proclaimed the Universal Declaration of Human Rights. Article 26 of the Declaration affirmed that:

Everyone has the right to education. Education shall be free, at least in the elementary and fundamental stages. Elementary education shall be compulsory. Technical and professional education shall be made generally available and higher education shall be equally accessible to all on the basis of merit.

Education shall be directed to the full development of the human personality and to the strengthening of respect for human rights and fundamental freedoms. It shall promote understanding, tolerance and friendship among all nations, racial or religious groups, and shall further the activities of the United Nations for the maintenance of peace.

Parents have a prior right to choose the kind of education that shall be given to their children.

In the 60 years since the Declaration, changes have swept higher education. The emergence of online education promises that growth in its quality, scale and breadth could insure that education becomes a right.

Sloan-C research abundantly demonstrates that online education is effective for learning, especially for encouraging reflection, interaction, diversity and collaboration. It can take advantage of cost efficiencies, especially through curriculum redesign and shared resources. It provides access to more learners and more kinds of learners at their own chosen times and places. Although teaching and learning online may take more time and effort, the growth of online education in the United States to $20 \%$ of the entire college population shows that faculty and students readily engage online. Nevertheless, there is still tremendous potential for growth.

The eight papers in this special issue of the Journal of Asynchronous Learning Networks examine some of the roles that online education plays in implementing the right to education:

- In "BRICs and Clicks," Mary Bold, Nirisha K.Garimella, Lillian Chenoweth focus on understanding the potential of online education in the BRIC countries-- Brazil, Russia, India, and China-- and propose a typology for charting global developments in distance education.

- In "Microfranchising Microlearning Centers: A Sustainable Model for Expanding the Right to Education in Developing Countries?” Tiffany Zenith Ivins provides an example of how microfranchising can reach remote learners in low-tech, infrastructure-poor communities. 
- In "Determined to Learn: Accessing Education Despite Life-Threatening Disasters," Claudine SchWeber demonstrates that online education provides resilience and continuity of education even in crises such as the aftermath of Hurricane Katrina and in war-torn Lebanon.

- In the U.S., says Katrina Meyer in "If Higher Education Is a Right, and Distance Education Is the Answer, Then Who Will Pay?” investing in the people and processes can achieve cost efficiencies for significantly scaling access to education.

- In "Bringing the Real World of Science to Children: A Partnership of the American Museum of Natural History and the City University of New York" Tony Picciano and Robert Steiner demonstrate how partnerships can reduce inequities by bringing qualified teachers and resources to the poor, underserved, and underprivileged, especially in muchneeded subjects such as science, mathematics, and technology.

- In "Open Educational Resources for Blended Learning in High Schools: Overcoming Impediments in Developing Countries," Richard Larson and Elizabeth Murray examine the High School Blended Learning Open Source Science or Math Studies Initiative (BLOSSOMS) project. Blossoms is an OER initiative that surmounts barriers to access in developing countries by encouraging mutual collaboration across borders and among module producers and users in over fifteen countries.

- In "Access to Education with Online Learning and Open Educational Resources: Can they close the gap?” Christine Geith and Karen Vignare compare and contrast OER and online learning and their potential for financial sustainability and for closing the global education gap.

- In “An Online Learning Model to Facilitate Learners' Rights to Education” Lin Lin affirms an online pedagogy of independent, collaborative, and formative inquiry. These habits of inquiry inculcate rights to freedom of thought, freedom to assemble and to be part of a community, and the right to transformational education.

The 1948 Declaration called for free and compulsory education with choice and equal access based on merit. The studies in this issue propose identifying metrics for progress towards universal access, using online education for continuity of learning despite disasters, stewarding resources, marshalling partnerships, and designing learning that promotes the values of the Declaration: 'respect, understanding, tolerance, friendship, and peace.' 